\title{
The role of the cerebellum in schizophrenia: from cognition to molecular pathways
}

\author{
Peyman Yeganeh-Doost,' Oliver Gruber,' Peter Falkai,' Andrea Schmitt',"II \\ 'Department of Psychiatry, University of Göttingen, 37075 Göttingen, Germany. "Laboratory of Neuroscience (LIM27), Institute of Psychiatry, University of \\ Sao Paulo, São Paulo, Brazil.
}

\begin{abstract}
Beside its role in motor coordination, the cerebellum is involved in cognitive function such as attention, working memory, verbal learning, and sensory discrimination. In schizophrenia, a disturbed prefronto-thalamo-cerebellar circuit has been proposed to play a role in the pathophysiology. In addition, a deficit in the glutamatergic N-methylD-aspartate (NMDA) receptor has been hypothesized. The risk gene neuregulin 1 may play a major role in this process. We demonstrated a higher expression of the NMDA receptor subunit 2D in the right cerebellar regions of schizophrenia patients, which may be a secondary upregulation due to a dysfunctional receptor. In contrast, the neuregulin 1 risk variant containing at least one C-allele was associated with decreased expression of NMDA receptor subunit $2 \mathrm{C}$, leading to a dysfunction of the NMDA receptor, which in turn may lead to a dysfunction of the gamma amino butyric acid (GABA) system. Accordingly, from post-mortem studies, there is accumulating evidence that GABAergic signaling is decreased in the cerebellum of schizophrenia patients. As patients in these studies are treated with antipsychotics long term, we evaluated the effect of long-term haloperidol and clozapine treatment in an animal model. We showed that clozapine may be superior to haloperidol in restoring a deficit in NMDA receptor subunit $2 \mathrm{C}$ expression in the cerebellum. We discuss the molecular findings in the light of the role of the cerebellum in attention and cognitive deficits in schizophrenia.
\end{abstract}

KEYWORDS: Schizophrenia; Cerebellum; N-methyl D-aspartate receptor; Gamma amino butyric acid; Antipsychotics.

Yeganeh-Doost P, Gruber O, Falkai P, Schmitt A. The role of the cerebellum in schizophrenia: from cognition to molecular pathways. Clinics. 2011;66(S1):71-77.

Received for publication on March 2, 2011; Accepted for publication on March 3, 2011

E-mail: aschmit@gwdg.de

Tel.: 00495513910366

\section{INTRODUCTION}

Schizophrenia has a worldwide prevalence of about $1 \%$ and mainly strikes young adults between the ages of 20 and 35 years. It is a severe psychiatric disorder leading to lifelong disability in more than $50 \%$ of sufferers and therefore constitutes one of the 10 most costly illnesses worldwide. ${ }^{1}$ The course of the disease is heterogeneous with approximately $50 \%$ of patients requiring one or more readmissions during follow-up. Only $20 \%$ of patients will be able to gain full employment and only $30 \%$ maintain a stable relationship. ${ }^{2}$

Schizophrenia has been regarded as a syndrome. In recent decades, symptom classifications have been calculated in four or five main domains. These include positive symptoms with exaggeration of normal function, such as hallucinations, delusions, disorganized speech, and disorganized behavior. The negative symptoms comprise a diminution in mental functions, such as blunting, avolition, alogia, and anhedonia, and a deficit in social interaction. ${ }^{3,4}$ Besides affective symptoms (e.g., depressive mood), another domain refers to cognitive symptoms with declarative episodic and working memory as well as attention, which

Copyright (c) 2011 CLINICS - This is an Open Access article distributed under the terms of the Creative Commons Attribution Non-Commercial License (http:// creativecommons.org/licenses/by-nc/3.0/) which permits unrestricted noncommercial use, distribution, and reproduction in any medium, provided the original work is properly cited. possess special relevance for schizophrenia. ${ }^{5-8}$ Especially persistent cognitive deficits are very reliable predictors of a relapse and therefore an unfavorable long-term outcome..$^{9,10}$ Further concepts of phenotypes include the appearance of neurological soft signs such as dysdiadochokinesis or deficits in motor coordination ${ }^{11,12}$ and eye tracking abnormalities with deficits in smooth pursuit eye movements. ${ }^{13,14}$ However, the pathophysiology of the disease is broadly unknown.

\section{Pathophysiology}

The dopamine hypothesis of schizophrenia postulating a dopaminergic hyperactivity in the limbic circuitry is based on the evidence of typical neuroleptics with a D2-dopamine antagonism being effective in the treatment of positive symptoms. ${ }^{15}$ The glutamate hypothesis of schizophrenia is based on the observation that phencyclidine and ketamine, which block the ion channel of the glutamatergic N-methylD-aspartate (NMDA) receptor and initiate NMDA hypofunction, precipitate psychosis. This psychosis not only models the positive symptoms of schizophrenia, but patients even develop a chronic deteriorative psychosis that resembles the deficit state of schizophrenia. ${ }^{16,17}$

To date, the prevailing hypothesis of schizophrenia is that multifactorial interactions between risk genes and environmental factors impact both early and late brain developmental changes. Several lines of evidence support this neurodevelopmental hypothesis. ${ }^{18}$ In recent years, several 
risk genes such as dysbindin, DAOA (D-amino acid oxidase activator), COMT (catechol-O-methyltransferase), and RSG4 and neuregulin 1 (NRG-1) have been identified, each contributing a small amount to the risk of developing the disease. Most of these genes such as NRG-1 are hypothesized to affect the glutamatergic NMDA receptor. ${ }^{19}$ Mutations in NRG-1 have been identified on chromosome 8 p21 in schizophrenia. ${ }^{19,20}$ In post-mortem studies, several isoforms have been shown to be differentially expressed in schizophrenia, possibly contributing to the pathophysiology of the disease. ${ }^{21,22}$

\section{Disturbances in neuronal networks}

Since the beginning of the last century, schizophrenia has been regarded as a brain disorder. Neurotransmitter hypotheses postulated disturbances in the dopaminergic and glutamatergic system. ${ }^{23,24}$ Structural, functional, and spectroscopic magnetic resonance imaging (MRI) as well as diffusion tensor imaging studies revealed alterations in fronto-temporal-thalamic-cerebellar networks including the heteromodal association cortex and hippocampus with resulting disturbances in macro- and microconnectivity. ${ }^{25,26}$ At the cellular and molecular level, deficits in the number and function of oligodendrocytes and myelin components as well as synaptic proteins are prominent. ${ }^{27-30}$ They may be related to neurodevelopmental disturbances and, in subgroups of patients, an additional non-typical neurodegenerative component. It has been hypothesized that the disorder originates from brain neurodevelopmental neuropathology with symptoms and neuropsychological deficits arising from alterations in precisely defined brain regions or functional neuronal circuits. ${ }^{31}$

The thalamus acts as a central relay station, transferring peripheral sensory inputs to the cortex and receiving projections from the cerebellum. It plays a critical role in filtering sensory information, in regulating cognitive input to the cortex, and in mediating corticocortical connections between areas particularly implicated in schizophrenia, such as the frontal and temporal regions. In schizophrenia patients, positron emission tomography (PET) studies show a dysfunction of the cortico-cerebellar-thalamic-cortical neuronal circuit (Figure 1) contributing to "cognitive dysmetria", i.e., impaired cognition and other symptoms of the disease: ${ }^{32,33}$ the inability to receive and process information rapidly, to retrieve the relevant associated constructs, and to produce a well-modulated and fine-tuned response. Thus, schizophrenia patients have subtle abnormalities of posture, gait, emotional response and expression, and cognitive performance.

\section{Cerebellum and cognition: evidence from schizophrenia}

The cerebellar cortex is divided into three different cellular layers containing five different types of glutamatergic and gamma amino butyric acid (GABA)ergic neurons (Figure 2). Inputs to the cerebellum are from excitatory climbing fibers from the inferior olive and from glutamatergic mossy fibers connecting the brainstem and cerebral cortex with the cerebellum via the pons ${ }^{34}$ (Figure 2). It has been shown that, by connection via the thalamus, the cerebellum innervates not only motor areas of the cortex, but also prefrontal and parietal heteromodal association cortices involved in cognition. ${ }^{35}$ First insights revealed that the cerebellum is known to be involved in predicting motor

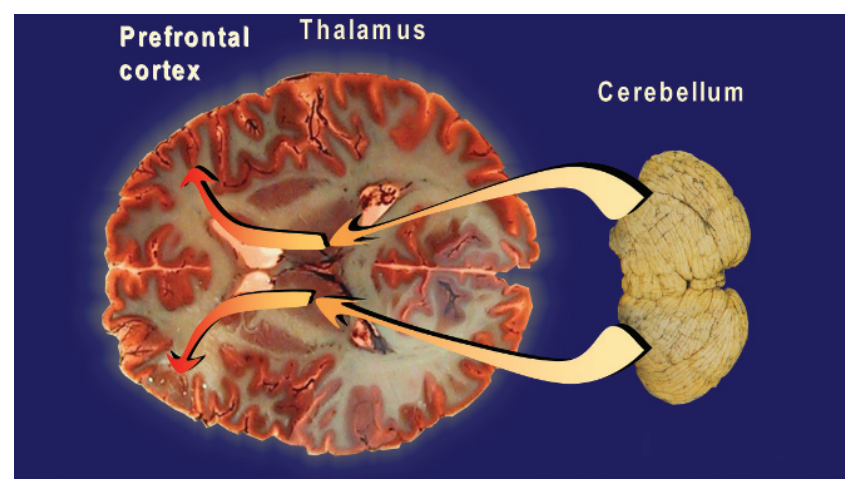

Figure 1 - The connections of the cerebellum. It is projecting to the thalamus and prefrontal cortex. Disturbances of this circuit have been proposed to play a role in the pathophysiology of schizophrenia.

control of movement outcomes. ${ }^{36}$ After cerebellar damage, neurocognitive symptoms and a cognitive affective syndrome including blunted affect and inappropriate behavior have been shown. ${ }^{37}$ In addition, lesions of the lateral cerebellum impair cognitive functions including speech, and induce mutism and amnestic aphasia. The right cerebellum, in connection with the dorsolateral prefrontal cortex, is involved in executive and working memory functions, e.g., subvocal rehearsal mechanisms of verbal working memory. ${ }^{38-42}$

In addition, PET and functional magnetic resonance (fMRI) studies have demonstrated the involvement of the cerebellum in different cognitive tasks: sensory discrimination, ${ }^{43}$ attention $^{44-46}$ or, more recently, the attentional part of working memory demands, ${ }^{38,47}$ semantic association, ${ }^{48}$ verbal learning and memory, ${ }^{49}$ visuospatial functions, ${ }^{50}$ and complex problem solving. ${ }^{51}$ The cerebellum has also been linked to higher order cognitive control processes referred to as executive functions. ${ }^{52,53}$ All these domains are disturbed in schizophrenia patients. ${ }^{54}$ In a series of fMRI and behavioral studies, we investigated the functional integrity of distinct brain systems underlying maintenance-related subprocesses of working memory (articulatory rehearsal, non-articulatory maintenance of phonological information, maintenance of visuospatial information) in patients with schizophrenia and other major psychoses. ${ }^{55-59}$ By means of circuit-specific experimental paradigms, we were able to provide first evidence for a possible subtype of schizophrenia with a selective dysfunction of the articulatory subsystem of verbal working memory, which functionally involves the cerebellum. ${ }^{60,61}$ Moreover, we were able to show that familial (and probably also genetic) loading impacts on the functional integrity of this articulatory rehearsal mechanism in schizophrenia, $^{62}$ suggesting that selective dysfunction of this mechanism may characterize a schizophrenia subtype with a more homogeneous underlying pathophysiology and genetic etiology. 60,63

\section{Brain imaging studies of the cerebellum in schizophrenia}

In recent decades, the cerebellum has been implicated in the pathophysiology of schizophrenia, with the corticothalamo-cerebellar circuit ${ }^{33}$ receiving particular attention. Schizophrenia patients reveal deficits supporting impairment of cerebellar functions: neurological soft signs, 


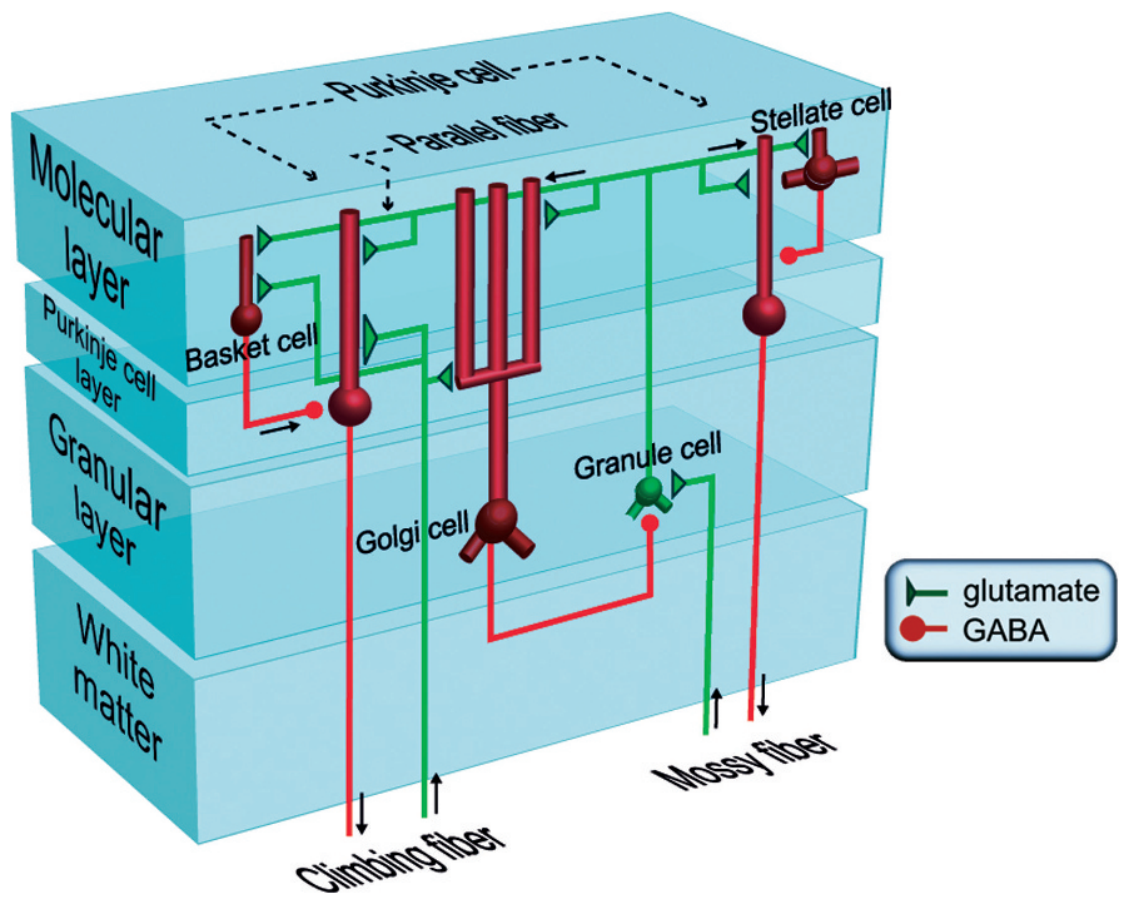

Figure 2 - The cerebellum contains three layers and five distinct types of neurons. Glutamatergic neurons are shown in green and GABAergic neurons in red. In schizophrenia, a deficit in the glutamatergic NMDA receptor may lead to a GABAergic deficit and, as a consequence, to disturbed glutamatergic projections.

dyscoordination, abnormal posture, impaired eyeblink conditioning, procedural learning deficits, and poor cognitive performance. ${ }^{64}$ Neurological soft signs were correlated with reduced gray matter volumes in the cerebellum and related networks. ${ }^{65,66}$ Structural MRI studies revealed decreased volumes of the total cerebellum, left cerebellar hemisphere, and right vermis, ${ }^{67,68}$ as well as correlation of the volume reduction with psychopathological subscores. ${ }^{69,70}$ Evidence from PET as well as fMRI studies investigating resting state or working memory and periodic sequence learning tasks has shown decreased activation of cerebellar subregions. $54,67,71$

${ }^{1} \mathrm{H}$-spectroscopic MRI studies have revealed decreased $\mathrm{N}$ acetylaspartate (NAA) and creatine in the anterior vermis and cortex, pointing to altered neuronal integrity of neurons, dendrites, and axons. ${ }^{72,73}$ Reduction in NAA indicates a loss of functional and structural integrity of neurons, dendrites, and axons. Such neuronal dysfunction may involve a glutamatergic deficit in the cerebellar subregions of schizophrenic patients.

\section{The cerebellar glutamate system and schizophrenia}

An NMDA receptor hypofunction has been proposed to play a role in schizophrenia, ${ }^{24}$ resulting in a final hypoglutamatergic state of corticostriatal projections. ${ }^{24,74}$ The NMDA receptor is composed of different subunits responsible for various functional properties. ${ }^{75,76}$ The obligate NR1 subunit combines two or three NR2 subunits (NR2A, NR2B, NR2C, and NR2D) to form the functional receptor. Studies using brain tissue obtained post mortem have examined the expression of glutamate receptor subunits, and support the hypothesis of a glutamate dysfunction in schizophrenia. ${ }^{77}$

In cerebellar Purkinje and Golgi neurons, all NMDA receptor subunits are expressed ${ }^{78,79}$ and may be altered in schizophrenia. In the left cerebellum, a study by Akbarian et al. ${ }^{81}$ found no differences in NMDA receptor expression. To determine whether NMDA receptor alteration is present in the right and left cerebellar vermis and hemispheres in schizophrenia, we measured NMDA receptor binding and gene expression of the NMDA receptor subunits in a postmortem study of elderly patients with schizophrenia and non-affected subjects. The results revealed a significantly higher expression of the NR2D subunit in the right-side anterior hemisphere and vermis compared with our group of normal elderly control subjects. In contrast, we found no difference in NR2D expression in the left cerebellar subregions as well as levels of NR1, NR2A, NR2B, and NR2C expression. ${ }^{80}$ These results point in the same direction as increased expression of NR2D subunit in the left prefrontal cortex. ${ }^{81}$ In contrast to receptors containing a combination of NR1 with NR2A or NR2B subunits, NMDA receptors assembled from NR1 and NR2D subunits show a prolonged decay rate of glutamate-induced ion currents and a lowered threshold for a voltage-dependent magnesium blockade. ${ }^{76,77}$ This causes "hyperexcitable" counteracting reduced postsynaptic activity. Therefore, increased expression of the NR2D subunit in schizophrenic patients may be interpreted as a secondary regulation to glutamatergic hypoactivity in the right cerebellum.

As the expression of the NR2C subunit has been reported to be regulated by NRG-1 maturing synapses of the cerebellar granule cells, ${ }^{82}$ and thus the NRG-1 risk genotype may alter the expression or function of the NMDA receptor in the cerebellar subregions, we genotyped the samples for the NRG1 polymorphism rs35753505 (SNP8NRG221533). This variant forms part of the previously reported risk haplotype for schizophrenia, and has been described as a tagging single nucleotide polymorphism (SNP) of the core 
at-risk haplotype. ${ }^{19,83}$ Positive association findings with this risk gene and schizophrenia and schizophrenic-related phenotypes have been reported in several studies. ${ }^{84-94}$ In both groups in our post-mortem study, the NRG1 SNP8NRG221533 schizophrenia-risk genotypes containing at least one C-allele (CC and CT) decreased gene expression of the NR2C subunit in the molecular layer of the right vermis and hemisphere compared with the TT genotype. Again, on the left side, we found no genotype-specific differences. ${ }^{80}$ This finding was confined to the molecular layer of the right cerebellum. Decreased expression may lead to an NMDA receptor hypofunction, as NR2C, as a major NMDA receptor subunit of the cerebellum, exhibits less marked voltage-sensitive magnesium blockade and a prolonged decay rate of glutamate-induced ion currents. ${ }^{76}$ A deficiency in this subunit may cause decreased receptor activation during glutamatergic stimulation and, as a consequence, diminished synaptic sprouting. Accordingly, in another post-mortem study, the glutamatergic synaptic protein complexin 2 was reduced at the mRNA and protein levels in the granule cell layer of the cerebellar cortex of schizophrenia patients compared with healthy control subjects, ${ }^{95}$ supporting the hypothesis of a glutamatergic dysfunction in schizophrenia.

Our results confirm that the cerebellum is lateralized and, as shown in an fMRI study, the right cerebellum and the left prefrontal cortex are both activated during a silent fluency task in right-handed healthy subjects. ${ }^{96}$

\section{Alterations in the cerebellar GABAergic system and at the cellular level}

Cognitive functioning depends on the plasticity mediated, in part, by NMDA receptors. A hypofunction of the NMDA receptor bearing on inhibitory GABAergic interneurons gives rise to reduced GABAergic inhibitory tone. In the long term, these target neurons could be injured by increased neurotransmission at ionotropic glutamatergic AMPA $(( \pm)-$ $\alpha$-amino-3-hydroxy-5-methylisoxazole-4-propionoc acid), kainite, and cholinergic receptors with subsequent cell damage and a final hypoglutamatergic state.$^{24,74,97}$ Thus, an NMDA receptor hypofunction and a GABAergic deficit of interneurons may both result in disturbed pathways at the molecular and cellular levels. Indeed, there is evidence of impaired interneuron function. For example, the GABA synthesizing enzyme glutamic acid decarboxylase 67 (GAD67) and reelin, both expressed in GABAergic interneurons, have been reported to be downregulated at the mRNA and protein levels in the cerebellum of schizophrenia patients. ${ }^{98,99}$ Besides GAD67, GAD56 and the GABA transporter 1 have been shown to be downregulated along with increased $\mathrm{GABA}_{\mathrm{A}}$ receptor subunits, pointing to a deficit in GABAergic neurotransmission. ${ }^{100}$ This may be related to a deficit in the NMDA receptor, as its antagonist phencyclidine causes similar alterations in cerebellar Golgi cells. ${ }^{101}$ However, altered cell numbers of Golgi cells remain to be investigated. In contrast, the cell density of GABAergic Purkinje neurons has been reported to be decreased in schizophrenia patients and heterozygous reeler mice with a deficit in reelin expression. ${ }^{102}$

\section{Influence of antipsychotic treatment}

As all patients involved in post-mortem studies had been treated with antipsychotics for decades, medication effects may have influenced the results. Accordingly, we con- ducted an additional animal study closely investigating the effects of a typical (haloperidol) and an atypical (clozapine) antipsychotic medication on NMDA receptor binding and gene expression of subunits of the NMDA receptor in different cerebellar rat brain regions after drug administration for up to 6 months. Here, we demonstrated that expression of NR2C was increased in clozapine-treated animals compared with haloperidol treatment. Therefore, clozapine may be superior to haloperidol in restoring a deficit in NR2C expression in the right cerebellum. ${ }^{80}$ In an animal study of antipsychotic treatment, both haloperidol and clozapine increased the GABAergic marker GAD67 in the cerebellum. ${ }^{100}$

We hypothesize that atypical antipsychotics may restore brain function by influencing the glutamatergic system and consecutive changes in neuroplasticity and brain activation. For example, antipsychotics are known to influence gray matter volumes in the cortex and, after 8 weeks of treatment, a volume increase has been found in the bilateral cerebellum as well. ${ }^{103}$ A recent fMRI study during saccades to visual targets revealed less activation of the cerebellum and related networks in antipsychotic-naïve first-episode schizophrenia patients and the restoring effects of subchronic treatment with the atypical antipsychotic risperidone. ${ }^{104}$ During presentation of pictures of facial emotions of happy faces, risperidone activated the right cerebellum compared with treatment with typical neuroleptics, suggesting superior effects of atypical antipsychotics. ${ }^{105}$ As a glutamatergic deficit in the cerebellum may contribute to cognitive symptoms in the disease, medication with glutamate agonists may be beneficial in chronic schizophrenia.

\section{ACKNOWLEDGMENT}

This study was supported by the European Commission under the Sixth Framework Programme (BrainNet Europe II, LSHM-CT-2004-503039). The paper reflects only the authors' views and the Community is not liable for any use that may be made of it.

\section{REFERENCES}

1. Murray CJ, Lopez AD. Evidence-based health policy - lessons from the Global Burden of Disease Study. Science. 1996;274:740-3, doi: 10.1126/ science.274.5288.740.

2. Häfner $H$, an der Heiden W. Course and outcome of schizophrenia. In: Hirsch \& Weinberger (Hrsg.). Schizophrenia. Oxford: Blackwell Publishing; 2003. pp. 101-39.

3. Crow TJ. Molecular pathology of schizophrenia: more than one disease process? Br Med J. 1980;280:66-8, doi: 10.1136/bmj.280.6207.66.

4. Andreasen NC. Negative symptoms in schizophrenia: definition and reliability. Arch Gen Psychiatry. 1982;39:784-8.

5. Albus M, Hubmann W, Scherer J, Dreikorn B, Hecht S, Sobizack N, et al. A prospective 2-year follow-up study of neurocognitive functioning in patients with first-episode schizophrenia. Eur Arch Psychiatry Clin Neurosci. 2002;252:262-7, doi: 10.1007/s00406-002-0391-4

6. Albus M, Hubmann W, Mohr F, Hecht S, Hinterberger-Weber P, Seitz $\mathrm{NN}$, et al. Neurocognitive functioning in patients with first-episode schizophrenia: results of a prospective 5-year follow-up study. Eur Arch Psychiatry Clin Neurosci. 2006;256:442-51, doi: 10.1007/s00406006-0667-1.

7. Hoff AL, Harris D, Faustman WO, Beal M, DeVilliers D, Mone RD, et al. A neuropsychological study of early onset schizophrenia. Schizophr Res. 1996;20:21-8, doi: 10.1016/0920-9964(95)00065-8.

8. Hoff AL, Svetina C, Shields G, Stewart J, DeLisi LE. Ten year longitudinal study of neuropsychological functioning subsequent to a firs episode of schizophrenia. Schizophr Res. 2005;78:27-34.

9. Robinson DG, Woerner MG, Alvir JM, Bilder RM, Hinrichsen GA, Lieberman JA. Predictors of medication discontinuation by patients with first-episode schizophrenia and schizoaffective disorder. Schizophr Res. 2002;57:209-19, doi: 10.1016/S0920-9964(01)00312-7. 
10. Andreasen NC, Carpenter WTJr, Kane JM, Lasser RA, Marder SR, Weinberger DR. Remission in schizophrenia: proposed criteria and rationale for consensus. Am J Psychiatry. 2005;162:441-9, doi: 10.1176/ appi.ajp.162.3.441.

11. Heinrichs DW, Buchanan RW. Significance and meaning of neurological signs in schizophrenia. Am J Psychiatry. 1988;145:11-18.

12. Chen EY, Shapleske J, Luque R, McKenna PJ, Hodges JR, Calloway SP, et al. The Cambridge Neurological Inventory: a clinical instrument for assessment of soft neurological signs in psychiatric patients. Psychiatry Res. 1995;56:183-204, doi: 10.1016/0165-1781(95)02535-2.

13. Levy DL, Holzman PS, Matthysse S, Mendell NR. Eye tracking and schizophrenia: a selective review. Schizophr Bull. 1994;20:47-62.

14. Thaker GK, Ross DE, Cassady SL, Adami HM, Medoff DR, Sherr J. Saccadic eye movement abnormalities in relatives of patients with schizophrenia. Schizophr Res. 2000;45:235-44, doi: 10.1016/S09209964(99)00193-0.

15. Carlsson A. Neurocircuitries and neurotransmitter interactions in schizophrenia. Int Clin Psychopharmacol. 1995;10:21-8.

16. Javitt DC, Zukin SR. Recent advances in the phencyclidine model of schizophrenia. Am J Psychiatry. 1991;148:1301-8.

17. Jentsch JD, Roth RH. The neuropsychopharmacology of phencyclidine: from NMDA receptor hypofunction to the dopamine hypothesis of schizophrenia. Neuropsychopharmacology. 1999;20:201-25, doi: 10. 1016/S0893-133X(98)00060-8.

18. Weinberger DR. On the plausibility of "the neurodevelopmental hypothesis" of schizophrenia. Neuropsychopharmacology. 1996;14:1S11S, doi: 10.1016/0893-133X(95)00199-N

19. Harrison PJ, Weinberger DR. Schizophrenia genes, gene expression, and neuropathology: on the matter of their convergence. Mol Psychiatry. 2005;10:4068. Erratum in: Mol Psychiatry. 2005;10:420 and Mol Psychiatry. 2005;10:804, doi: 10.1038/sj.mp.4001558.

20. Harrison PJ, Weinberger DR. Schizophrenia genes, gene expression, and neuropathology: on the matter of their convergence. Mol Psychiatry. 2005;10:4068;image 5, doi: 10.1038/sj.mp.4001558.

21. Schmitt A, Parlapani E, Gruber O, Wobrock T, Falkai P. Impact of neuregulin-1 on the pathophysiology of schizophrenia in human postmortem studies. Eur Arch Psychiatry Clin Neurosci. 2008;258 (Suppl 5):35-9, doi: 10.1007/s00406-008-5019-x.

22. Parlapani E, Schmitt A, Wirths O, Bauer M, Sommer C, Rueb U, et al. Gene expression of neuregulin-1 isoforms in different brain regions of elderly schizophrenia patients. World J Biol Psychiatry. 2010;11:243-50, doi: 10.3109/15622970802022376.

23. Carlsson A, Waters N, Carlsson ML. Neurotransmitter interactions in schizophrenia-therapeutic implications. Eur Arch Psychiatry Clin Neurosci. 1999;249 (Suppl 4):37-43.

24. Olney JW, Farber NB. Glutamate receptor dysfunction and schizophrenia. Arch Gen Psychiatry. 1995;52:998-1007.

25. Schmitt A, Weber-Fahr W, Jatzko A, Tost H, Henn FA, Braus DF. [Current overview of structural magnetic resonance imaging in schizophrenia]. Fortschr Neurol Psychiatr. 2001;69:105-15, doi: 10. 1055/s-2001-12277.

26. Davis KL, Stewart DG, Friedman JI, Buchsbaum M, Harvey PD, Hof PR, et al. White matter changes in schizophrenia: evidence for myelinrelated dysfunction. Arch Gen Psychiatry. 2003;60:443-56, doi: 10.1001/ archpsyc.60.5.443.

27. Glantz LA, Lewis DA. Reduction of synaptophysin immunoreactivity in the prefrontal cortex of subjects with schizophrenia. Regional and diagnostic specificity. Arch Gen Psychiatry. 1997;54:660-9.

28. Eastwood SL, Harrison PJ. Hippocampal synaptic pathology in schizophrenia, bipolar disorder and major depression: a study of complexin mRNAs. Mol Psychiatry. 2000;5:425-32, doi: 10.1038/sj.mp. 4000741.

29. Honer WG, Falkai P, Bayer TA, Xie J, Hu L, Li HY, et al. Abnormalities of SNARE mechanism proteins in anterior frontal cortex in severe mental illness. Cereb Cortex. 2002;12:349-56, doi: 10.1093/cercor/12.4. 349.

30. Schmitt A, Steyskal C, Bernstein HG, Schneider-Axmann T, Parlapani E, Schaeffer EL, et al. Stereologic investigation of the posterior part of the hippocampus in schizophrenia. Acta Neuropathol. 2009;117:395-407, doi: 10.1007/s00401-008-0430-y.

31. Weinberger DR. On the plausibility of "the neurodevelopmental hypothesis" of schizophrenia. Neuropsychopharmacology. 1996;14:1S11S, doi: 10.1016/0893-133X(95)00199-N.

32. Andreasen NC, Arndt S, Swayze V2nd, Cizadlo T, Flaum M, O'Leary D, et al. Thalamic abnormalities in schizophrenia visualized through magnetic resonance image averaging. Science. 1994;266:294-8, doi: 10. $1126 /$ science.7939669.

33. Andreasen NC, Nopoulos P, O'Leary DS, Miller DD, Wassink T, Flaum $\mathrm{M}$. Defining the phenotype of schizophrenia: cognitive dysmetria and its neural mechanisms. Biol Psychiatry. 1999;46:908-20, doi: 10.1016/ S0006-3223(99)00152-3.

34. Thach WT. On the mechanism of cerebellar contributions to cognition. Cerebellum. 2007;6:163-7, doi: 10.1080/14734220701373530.
35. Middleton FA, Strick PL. Anatomical evidence for cerebellar and basal ganglia involvement in higher cognitive function. Science. 1994;266:458 61, doi: 10.1126/science.7939688.

36. Fuentes CT, Bastian AJ. "Motor cognition" - what is it and is the cerebellum involved? Cerebellum. 2007;6:232-6, doi: 10.1080/ 14734220701329268.

37. Baillieux H, Verslegers W, Paquier P, De Deyn PP, Mariën P. Cerebellar cognitive affective syndrome associated with topiramate. Clin Neurol Neurosurg. 2008;110:496-9, doi: 10.1016/j.clineuro.2008.01.003.

38. Gruber O. Effects of domain-specific interference on brain activation associated with verbal working memory task performance. Cerebral Cortex. 2001;11:1047-55, doi: 10.1093/cercor/11.11.1047.

39. Gruber O, von Cramon DY. The functional neuroanatomy of human working memory revisited. Evidence from 3-T fMRI studies using classical domain-specific interference tasks. NeuroImage. 2003;19:797809 .

40. Ackermann H, Mathiak K, Riecker A. The contribution of the cerebellum to speech production and speech perception: clinical and functional imaging data. Cerebellum. 2007;6:202-13, doi: 10.1080/ 14734220701266742 .

41. Klingberg T, Kawashima R, Roland PE. Activation of multi-modal cortical areas underlies short-term memory. Eur J Neurosci. 1996;8:196571, doi: 10.1111/j.1460-9568.1996.tb01340.x.

42. Ben-Yehudah G, Guediche S, Fiez JA. Cerebellar contributions to verbal working memory: beyond cognitive theory. Cerebellum. 2007;6:193201, doi: 10.1080/14734220701286195.

43. Gao JH, Parsons LM, Bower JM, Xiong J, Li J, Fox PT. Cerebellum implicated in sensory acquisition and discrimination rather than motor control. Science. 1996;272:545-47, doi: 10.1126/science.272.5261.545.

44. Courchesne E, Townsend J, Akshoomoff NA, Saitoh O, YeungCourchesne R, Lincoln AJ, et al. Impairment in shifting attention in autistic and cerebellar patients. Behav Neurosci. 1994;108:848-65, doi: 10.1037/0735-7044.108.5.848.

45. Courchesne E, Akshoomoff NA, Townsend J, Saitoh O. A model system for the study of attention and the cerebellum: infantile autism. Electroencephalogr Clin Neurophysiol Suppl. 1995;44:315-25.

46. Akshoomoff NA, Courchesne E. A new role for the cerebellum in cognitive operations. Behav Neurosci. 1992;106:731-38, doi: 10.1037/ 0735-7044.106.5.731.

47. Haarmeier T, Thier P. The attentive cerebellum - myth or reality? Cerebellum. 2007:6:177-83, doi: 10.1080/14734220701286187.

48. Martin A, Haxby JV, Lalonde FM, Wiggs CL, Ungerleider LG. Discrete cortical regions associated with knowledge of color and knowledge of action. Science. 1995;270:102-5, doi: 10.1126/science.270.5233.102.

49. Grasby PM, Frith CD, Friston KJ, Bench C, Frackowiak RS, Dolan RJ. Functional mapping of brain areas implicated in auditory-verbal memory function. Brain. 1993;116:1-20, doi: 10.1093/brain/116.1.1.

50. Molinari M, Leggio MG. Cerebellar information processing and visuospatial functions. Cerebellum. 2007;6:214-20, doi: 10.1080/ 14734220701230870

51. Kim SG, Uğurbil K, Strick PL. Activation of a cerebellar output nucleus during cognitive processing. Science. 1994;265:949-51, doi: 10.1126/ science.8052851.

52. Bellebaum C, Daum I. Cerebellar involvement in executive control. Cerebellum. 2007;6:184-92, doi: 10.1080/14734220601169707.

53. Gruber O, Karch S, Schlueter EK, Falkai P, Goschke T. Neural mechanisms of advance preparation in task switching. NeuroImage. 2006; 31:887-95, doi: 10.1016/j.neuroimage.2005.12.043.

54. Andreasen NC, Pierson R. The role of the cerebellum in schizophrenia. Biol Psychiatry. 2008;64:81-8, doi: 10.1016/j.biopsych.2008.01.003.

55. Gruber O, Gruber E, Falkai P. Articulatory rehearsal in verbal working memory: a possible neurocognitive endophenotype that differentiates between schizophrenia and schizoaffective disorder. Neurosci Lett. 2006;405:24-8, doi: 10.1016/j.neulet.2006.06.062.

56. Henseler I, Falkai P, Gruber O. A systematic fMRI investigation of the brain systems subserving different working memory components in schizophrenia. Eur J Neurosci. 2009;30:693-702, doi: 10.1111/j.14609568.2009.06850.x

57. Gruber O, Tost H, Henseler I, Schmael C, Scherk H, Ende G, et al. Pathological amygdala activation during working memory performance: evidence for a pathophysiological trait marker in bipolar affective disorder. Hum Brain Mapping. 2010;31:115-25.

58. Gruber O, Zilles D, Kennel J, Gruber E, Falkai P. A systematic experimental neuropsychological investigation of the functional integrity of working memory circuits in major depression. Eur Arch Psychiatry Clin Neurosci. 2011;261:179-84, doi: 10.1007/s00406-010-0165-3.

59. Henseler I, Falkai P, Gruber O. Disturbed functional connectivity within networks subserving domain-specific subcomponents of working memory in schizophrenia: relation to performance and clinical symptoms. J Psychiatric Res. 2010;44:364-72, doi: 10.1016/j.jpsychires. 2009.09.003.

60. Gruber O, Gruber E, Falkai P. Neural correlates of working memory deficits in schizophrenic patients: ways to establish neurocognitive 
endophenotypes of psychiatric disorders. Radiologe. 2005;45:153-60, doi: 10.1007/s00117-004-1155-0.

61. Zilles D, Gruber E, Falkai P, Gruber O. Patients with schizophrenia show deficits of working memory maintenance components in circuitspecific tasks. Eur Arch Psychiatry Clin Neurosci. 2010;260:519-25, doi: 10.1007/s00406-010-0107-0.

62. Zilles D, Burke S, Schneider-Axmann T, Falkai P, Gruber O. Diagnosisspecific effect of familial loading on verbal working memory in schizophrenia. Eur Arch Psychiatry Clin Neurosci. 2009;259:309-15, doi: 10.1007/s00406-009-0001-9.

63. Gruber O, Falkai P. From identification of neurofunctional systems to individualization of treatment for schizophrenic disorders. Nervenarzt. 2009;80:12-21, doi: 10.1007/s00115-008-2615-y.

64. Picard H, Amado I, Mouchet-Mages S, Olié JP, Krebs MO. The role of the cerebellum in schizophrenia: an update of clinical, cognitive, and functional evidences. Schizophr Bull. 2008;34:155-72, doi: 10.1093/ schbul/sbm049.

65. Venkatasubramanian G, Jayakumar PN, Gangadhar BN, Keshavan MS. Neuroanatomical correlates of neurological soft signs in antipsychoticnaive schizophrenia. Psychiatry Res. 2008;164:215-22, doi: 10.1016/j. pscychresns.2007.12.021.

66. Thomann PA, Wüstenberg T, Santos VD, Bachmann S, Essig M, Schröder J. Neurological soft signs and brain morphology in firstepisode schizophrenia. Psychol Med. 2008;39:371-9, doi: 10.1017/ S0033291708003656.

67. Konarski JZ, McIntyre RS, Grupp LA, Kennedy SH. Is the cerebellum relevant in the circuitry of neuropsychiatric disorders? J Psychiatry Neurosci. 2005:30:178-86.

68. Volz H, Gaser C, Sauer H. Supporting evidence for the model of cognitive dysmetria in schizophrenia - a structural magnetic resonance imaging study using deformation-based morphometry. Schizophr Res. 2000;46:45-56, doi: 10.1016/S0920-9964(99)00236-4

69. Ichimiya T, Okubo Y, Suhara T, Sudo Y. Reduced volume of the cerebellar vermis in neuroleptic-naive schizophrenia. Biol Psychiatry. 2001;49:20-7, doi: 10.1016/S0006-3223(00)01081-7.

70. Okugawa G, Sedvall G, Nordström M, Andreasen N, Pierson R, Magnotta V, et al. Selective reduction of the posterior superior vermis in men with chronic schizophrenia. Schizophr Res. 2002;55:61-7, doi: 10. 1016/S0920-9964(01)00248-1.

71. Andreasen NC, Calarge CA, O'Leary DS. Theory of mind and schizophrenia: a positron emission tomography study of medicationfree patients. Schizophr Bull. 2008;34:708-19. Erratum in: Schizophr Bull. 2009;35:1030. Calage, Chadi A [corrected to Calarge, Chadi A], doi: $10.1093 /$ schbul/sbn034.

72. Deicken RF, Feiwell R, Schuff N, Soher B. Evidence for altered cerebellar vermis neuronal integrity in schizophrenia. Psychiatry Res. 2001;107:125-34, doi: 10.1016/S0925-4927(01)00103-2.

73. Ende G, Hubrich P, Walter S, Weber-Fahr W, Kämmerer N, Braus DF, et al. Further evidence for altered cerebellar neuronal integrity in schizophrenia. Am J Psychiatry. 2005;162:790-2, doi: 10.1176/appi.ajp. 162.4.790.

74. Farber NB, Newcomer JW, Olney JW. Glycine agonists: what can they teach us about schizophrenia? Arch Gen Psychiatry. 1999;56:13-17, doi: 10.1001/archpsyc.56.1.13.

75. Ishii T, Moriyoshi K, Sugihara H, Sakurada K, Kadotani H, Yokoi M, et al. Molecular characterization of the family of the N-methyl-Daspartate receptor subunits. J Biol Chem. 1993;268:2836-43.

76. Monyer H, Burnashev N, Laurie DJ, Sakmann B, Seeburg PH. Developmental and regional expression in the rat brain and functional properties of four NMDA receptors. Neuron. 1994;12:529-40, doi: 10. 1016/0896-6273(94)90210-0.

77. Schmitt A, Zink M, Müller B, May B, Herb A, Jatzko A, et al. Effects of long-term antipsychotic treatment on NMDA receptor binding and gene expression of subunits. Neurochem Res. 2003; 28:235-41, doi: 10. 1023/A:1022325116309.

78. Cull-Candy SG, Brickley SG, Misra C, Feldmeyer D, Momiyama A, Farrant M. NMDA receptor diversity in the cerebellum: identification of subunits contributing to functional receptors. Neuropharmacology. 1998;37:1369-80, doi: 10.1016/S0028-3908(98)00119-1

79. Scherzer CR, Landwehrmeyer GB, Kerner JA, Standaert DG, Hollingsworth ZR, Daggett LP, et al. Cellular distribution of NMDA glutamate receptor subunit mRNAs in the human cerebellum. Neurobiol Dis. 1997;4:35-46, doi: 10.1006/nbdi.1997.0136.

80. Schmitt A, Koschel J, Zink M, Bauer M, Sommer C, Frank J, et al. Gene expression of NMDA receptor subunits in the cerebellum of elderly patients with schizophrenia. Eur Arch Psychiatry Clin Neurosci. 2010;260:101-11, doi: 10.1007/s00406-009-0017-1.

81. Akbarian S, Sucher NJ, Bradley D, Tafazzoli A, Trinh D, Hetrick WP, et al. Selective alterations in gene expression for NMDA receptor subunits in prefrontal cortex of schizophrenics. J Neurosci. 1996;16:19-30.

82. Ozaki M, Sasner M, Yano R, Lu HS, Buonanno A. Neuregulin-beta induces expression of an NMDA-receptor subunit. Nature. 1997;390: $691-4$.
83. Law AJ, Lipska BK, Weickert CS, Hyde TM, Straub RE, Hashimoto R, et al. Neuregulin 1 transcripts are differentially expressed in schizophrenia and regulated by 5 ' SNPs associated with the disease. Proc Natl Acad Sci USA. 2006;103:6747-52, doi: 10.1073/pnas.0602002103.

84. Bakker SC, Hoogendoorn ML, Selten JP, Verduijn W, Pearson PL, Sinke RJ, et al. Neuregulin 1: genetic support for schizophrenia subtypes. Mol Psychiatry. 2004;9:1061-3, doi: 10.1038/sj.mp.4001564.

85. Bramon E, Dempster E, Frangou S, Shaikh M, Walshe M, Filbey FM, et al. Neuregulin-1 and the P300 waveform - a preliminary association study using a psychosis endophenotype. Schizophr Res. 2008;103:17885, doi: 10.1016/j.schres.2008.03.025.

86. Georgieva L, Dimitrova A, Ivanov D, Nikolov I, Williams NM, Grozeva $\mathrm{D}$, et al. Support for neuregulin 1 as a susceptibility gene for bipolar disorder and schizophrenia. Biol Psychiatry. 2008;64:419-27, doi: 10. 1016/j.biopsych.2008.03.025.

87. Hänninen K, Katila H, Saarela M, Rontu R, Mattila KM, Fan M, et al. Interleukin-1 beta gene polymorphism and its interactions with neuregulin-1 gene polymorphism are associated with schizophrenia. Eur Arch Psychiatry Clin Neurosci. 2008;258:10-15, doi: 10.1007/ s00406-007-0756-9.

88. Kampman O, Anttila S, Illi A, Saarela M, Rontu R, Mattila KM, et al. Neuregulin genotype and medication response in Finnish patients with schizophrenia. Neuroreport. 2004;15:2517-20, doi: 10.1097/00001756200411150-00017.

89. Kircher T, Thienel R, Wagner M, Reske M, Habel U, Kellermann T, et al. Neuregulin 1 ICE-single nucleotide polymorphism in first episode schizophrenia correlates with cerebral activation in fronto-temporal areas. Eur Arch Psychiatry Clin Neurosci. 2009;259:72-9, doi: 10.1007/ s00406-008-0837-4.

90. Stefansson H, Sarginson J, Kong A, Yates P, Steinthorsdottir V, Gudfinnsson E, et al. Association of neuregulin 1 with schizophrenia confirmed in a Scottish population. Am J Hum Genet. 2003;72:83-7, doi: $10.1086 / 345442$

91. Stefansson H, Sigurdsson E, Steinthorsdottir V, Bjornsdottir S, Sigmundsson T, Ghosh S, et al. Neuregulin 1 and susceptibility to schizophrenia. Am J Hum Genet. 2002;71:877-92, doi: 10.1086/ 342734 .

92. Winterer G, Konrad A, Vucurevic G, Musso F, Stoeter P, Dahmen N. Association of $5^{\prime}$ end neuregulin-1 (NRG1) gene variation with subcortical medial frontal microstructure in humans. Neuroimage. 2008;40:712-18, doi: 10.1016/j.neuroimage.2007.12.041.

93. Yang JZ, Si TM, Ruan Y, Ling YS, Han YH, Wang XL, et al. Association study of neuregulin 1 gene with schizophrenia. Mol Psychiatry. 2003:8:706-9, doi: 10.1038/sj.mp.4001377.

94. Gruber O, Falkai P, Schneider-Axmann T, Schwab SG, Wagner M, Maier W. Neuregulin-1 haplotype $\mathrm{HAP}_{\mathrm{ICE}}$ is associated with reduced hippocampal volumes in schizophrenic patients and in non-affected family members. J Psychiatric Res. 2008;43:1-6, doi: 10.1016/j.jpsychires.2008.01.009.

95. Eastwood SL, Cotter D, Harrison PJ. Cerebellar synaptic protein expression in schizophrenia. Neuroscience. 2001;105:219-29, doi: 10. 1016/S0306-4522(01)00141-5.

96. Hubrich-Ungureanu P, Kaemmerer N, Henn FA, Braus DF. Lateralized organization of the cerebellum in a silent verbal fluency task: a functional magnetic resonance imaging study in healthy volunteers. Neurosci Lett. 2002;319:91-4, doi: 10.1016/S0304-3940(01)02566-6.

97. Farber NB, Newcomer JW, Olney JW. Are glycine sites saturated in vivo? Arch Gen Psychiatry. 2000;57:1181-3, doi: 10.1001/archpsyc.57.12.1165.

98. Guidotti A, Pesold C, Costa E. New neurochemical markers for psychosis: a working hypothesis of their operation. Neurochem Res. 2000;25:1207-18, doi: 10.1023/A:1007635927069.

99. Fatemi SH, Stary JM, Earle JA, Araghi-Niknam M, Eagan E. GABAergic dysfunction in schizophrenia and mood disorders as reflected by decreased levels of glutamic acid decarboxylase 65 and $67 \mathrm{kDa}$ and Reelin proteins in cerebellum. Schizophr Res. 2005;72:109-22. Erratum in: Schizophr Res. 2005;74:287. Hossein Fatemi, S [corrected to Fatemi, S Hossein], doi: 10.1016/j.schres.2004.02.017.

100. Bullock WM, Cardon K, Bustillo J, Roberts RC, Perrone-Bizzozero NI. Altered expression of genes involved in GABAergic transmission and neuromodulation of granule cell activity in the cerebellum of schizophrenia patients. Am J Psychiatry. 2008;165:1594-603, doi: 10.1176/ appi.ajp.2008.07121845.

101. Bullock WM, Bolognani F, Botta P, Valenzuela CF, Perrone-Bizzozero NI. Schizophrenia-like GABAergic gene expression deficits in cerebellar Golgi cells from rats chronically exposed to low-dose phencyclidine. Neurochem Int. 2009;55:775-82, doi: 10.1016/j.neuint.2009.07.010.

102. Maloku E, Covelo IR, Hanbauer I, Guidotti A, Kadriu B, Hu O et al. Lower number of cerebellar Purkinje neurons in psychosis is associated with reduced reelin expression. Proc Natl Acad Sci USA. 2010;107:440711, doi: 10.1073/pnas.0914483107.

103. Deng MY, McAlonan GM, Cheung C, Chiu CP, Law CW, Cheung V, et al. A naturalistic study of grey matter volume increase after early treatment in anti-psychotic naïve, newly diagnosed schizophrenia. Psychopharmacology (Berl). 2009;206:437-46, doi: 10.1007/s00213-009-1619-z. 
104. Keedy SK, Rosen C, Khine T, Rajarethinam R, Janicak PG, Sweeney JA. An fMRI study of visual attention and sensorimotor function before and after antipsychotic treatment in first-episode schizophrenia. Psychiatry Res. 2009;172:16-23, doi: 10.1016/j.pscychresns.2008.06.003.
105. Surguladze SA, Chu EM, Marshall N, Evans A, Anilkumar AP, Timehin C, et al. Emotion processing in schizophrenia: fMRI study of patients treated with risperidone long-acting injections or conventional depot medication. J Psychopharmacol. April 2010. [Epub ahead of print] 